\title{
Kinerja Bidan di Desa dalam Program Jaminan Pemeliharaan Kesehatan Masyarakat Miskin
}

\author{
Arfah Husna* Besral**
}

\begin{abstract}
Abstrak
Cakupan pelayanan kebidanan program Jaminan Pelayanan Kesehatan Masyarakat Miskin (JPKMM) di Kabupaten Aceh Selatan tahun 2006 yang belum mencapai target mengindikasikan kinerja bidan di desa dalam pelayanan kebidanan program JPKMM masih rendah. Penelitian ini bertujuan mengetahui kinerja bidan desa dan faktor-faktor yang berhubungan. Kinerja bidan desa diukur dengan melihat cakupan pelayanan kebidanan program JPKMM meliputi cakupan pemeriksaan kehamilan minimal 4 kali dan cakupan pertolongan persalinan. Disain penelitian yang digunakan adalah cross sectional dengan populasi seluruh bidan desa yang bertugas di Kabupaten Aceh Selatan tahun 2007. Sampel adalah bidan desa yang sudah bertugas minimal setahun yang berjumlah 104 orang. Disimpulkan bahwa sebagian besar kinerja bidan desa masih rendah (56\%). Faktor-faktor yang berhubungan dengan kinerja bidan desa adalah: tidak adanya pesaing, adanya pembinaan, pengetahuan dan motivasi. Faktor-faktor yang tidak berhubungan dengan kinerja bidan desa adalah umur, status pernikahan, status kepegawaian (PNS/PTT), domisili, jumlah desa, sikap, imbalan, kemampuan dan pendidikan. Disarankan kepada Dinas Kesehatan untuk memberikan pembinaan yang lebih intensif kepada bidan desa dan memberikan penghargaan untuk meningkatkan motivasinya. Disarankan kepada bidan di desa untuk terus-menerus melakukan peningkatan pelayanan kepada pasien dan selalu menerapkan prinsip 3S (salam, senyum dan sopan) serta proaktif mendatangi pasien ke rumahnya untuk memberikan pelayanan kebidanan ataupun memelihara hubungan sosial yang baik.
\end{abstract}

Kata kunci : Bidan desa, pelayanan

\begin{abstract}
This research aimed to find out the performance of village midwife and its determinant factors. The performance of midwifery service within the Jaminan Pemeliharaan Kesehatan Masyarakat Miskin (JPKMM) program was measured by the coverage of antenatal care and coverage of trained birth attendance. The design of this study is cross sectional and data was analyzed using univariate, bivarite, and multivariate logistic regression. The population was all village midwives (137 persons) in Aceh Selatan District in the year 2007. The sample was village midwife who has at least one year work experience in a certain village and it consists of 104 persons. The result shows that the performance of village midwife is still low (56\%). Multivariate logistic regression analysis confirmed that the dominant factor related to good performance were no competitor, good supervision, knowledge and motivation. Factors which not associated with performance were age, marital status, employee status, domicile, number of village to be covered, attitude, reward, and education. We recommend that the District Health Office must supervise intensively and giving more reward to improve work motivation. The village midwife should improve their quality of services and implement the $3 \mathrm{~S}$ principle (salam, senyum and sopan) and conducting home visit to provide maternal health services and to maintain good social relationship with the community
\end{abstract}

Key words : Village midwives, performance

*Bidang Pengembangan SDM Kesehatan Dinas Kesehatan Kabupaten Aceh Selatan, Jl. TR Angkasah Tapaktuan, Aceh Selatan (e-mail: arfaj_husna@yahoo.com)

**Departemen Biostatistik dan IImu Kependudukan FKM UI, Gd. A Lt. 2 Fakultas Kesehatan Masyarakat Universitas Indonesia, Kampus Baru UI Depok 16424 (e-mail: besral@ui.edu) 
Angka Kematian Ibu (AKI) di Indonesia masih tinggi (307 per 100.000 kelahiran hidup) dengan kausa utama langsung adalah komplikasi pada saat atau segera setelah persalinan. Penyebab tersebut dikenal dengan trias klasik yang meliputi pendarahan (28\%), eklampsia $(24 \%)$ dan infeksi $(11 \%)$, sedangkan penyebab tidak langsung antara lain adalah Kurang Energi Kronis (KEK) 37\% dan anemia 40\%.1 Visi Indonesia Sehat 2010, mencanangkan Making Pregnancy Safer (MPS) atau Gerakan Nasional Kehamilan yang aman dan kebijakan penempatan bidan di desa (bidan di desa) sejak tahun 1990/1991.2,3 AKI di Kabupaten Aceh Selatan masih tinggi yaitu sebesar 458 per 100.000 kelahiran hidup, sedangkan Angka Kematian Bayi (AKB) hampir sama dengan AKB nasional sebesar 36 per 1000 kelahiran hidup. ${ }^{1}$ Penempatan bidan di desa di wilayah kabupaten Aceh Selatan telah dilakukan secara bertahap sejak tahun 1991, sampai sekarang ini jumlah bidan di desa sebanyak 137 orang, ditinjau dari jumlah dan penyebarannya penempatan bidan desa belum mencakup keseluruh desa bahkan masih banyak bidan mempunyai tanggung jawab lebih dari satu desa. ${ }^{4}$

Berdasarkan data Dinas Kesehatan Kabupaten Aceh Selatan, hasil cakupan pelayanan kebidanan program Jaminan Pemeliharaan Kesehatan Masyarakat Miskin (JPKMM) selama tahun 2006 dengan sasaran $3.125 \mathrm{ibu}$ hamil adalah persalinan oleh tenaga kesehatan (Linakes) $81,76 \%$; kontak ibu hamil dengan tenaga kesehatan yang keempat kali (K4) 79,04\% dan kunjungan neonatal (KN2) $72,64 \% .^{5}$ Kinerja ini masih lebih rendah jika dibandingkan dengan standar yang telah ditetapkan oleh Depkes untuk program JPKMM yaitu persalinan oleh tenaga kesehatan (90\%), kontak ibu hamil dengan tenaga kesehatan yang keempat kali $(90 \%)$ dan kunjungan neonatal $(90 \%) .6$ Cakupan pelayanan kebidanan program JPKMM di Kabupaten Aceh Selatan tahun 2006 secara keseluruhan belum mencapai target yang ditetapkan oleh Departemen Kesehatan Republik Indonesia, hal ini menunjukkan kinerja bidan di desa dalam pelayanan kebidanan program JPKMM masih rendah dan perlu dikaji dan dianalisis lebih mendalam untuk mengetahui penyebabnya serta mencari alternatif solusi untuk mengatasinya.

Penelitian ini bertujuan untuk mengetahui gambaran kinerja bidan di desa dan faktor-faktor apa saja yang berhubungan dengan kinerja bidan di desa dalam pelayanan kebidanan program JPKMM di Kabupaten Aceh Selatan tahun 2007. Ada 3 (tiga) variabel yang berhubungan kinerja seseorang, yaitu variabel individu, variabel organiasi dan variabel psikologis. Variabel individu terdiri dari sub variabel kemampuan dan ketrampilan (mental dan fisik), latar belakang (keluarga, tingkat sosial dan pengalaman), demografis (umur, etnis dan jenis kelamin). Variabel organisasi terdiri dari sub variabel sumber daya, kepemimpinan, imbalan, struktur, desain pekerjaan. Variabel psikologis terdiri dari sub variabel persepsi, sikap, kepribadian, belajar dan motivasi. ${ }^{7}$ Pendapat Gibson, ${ }^{7}$ ini akan menjadi landasan bagi pengembangan kerangka konsep dalam penelitian ini.

\section{Metode}

Penelitian yang menggunakan disain penelitian potong lintang (cross sectional) ini dilakukan di Kabupaten Aceh Selatan, pada bulan Agustus 2007 sampai dengan Januari 2008. Populasi penelitian adalah bidan di desa yang ada dalam wilayah Kabupaten Aceh Selatan pada tahun 2007 sebanyak 137 orang. Sampel penelitian ini adalah bidan di desa yang sudah bertugas minimal 1 tahun. Kriteria lama tugas minimal 1 tahun diperlukan untuk menghitung kinerja minimal untuk satu tahun, berdasarkan perhitungan pada saat program JPKMM dilaksanakan bidan di desa tersebut sudah berada di desa dalam wilayah Kabupaten Aceh Selatan. Seluruh bidan yang memenuhi kriteria disertakan dalam penelitian ini sehingga jumlah sampel adalah 108 orang. Data di kumpulkan dengan menggunakan angket dengan kuesioner terstruktur yang dibagikan kepada responden untuk mendapatkan data mengenai kinerja bidan di desa dalam pelayanan kebidanan program JPKMM dan faktorfaktor yang berhubungan (yaitu variabel individu, variabel organiasi dan variabel psikologis). Analisis data menggunakan analisis univariat untuk menggambarkan distribusi frekuensi dan proporsi masing-masing. Analisis bivariat untuk melihat hubungan variabel independen dengan variabel dependen. Analisis multivariat dengan regresi logistik ganda untuk mengidentifikasi secara bersama-sama variabel yang berhubungan bermakna dengan kinerja bidan di desa. Kemaknaan diukur dengan menggunakan derajat kemaknaan (nilai-p) 5\%. Kinerja bidan di desa dalam Pelayanan Kebidanan Program Jaminan Pemeliharaan Kesehatan Masyarakat Miskin diukur dengan cara wawancara dan telaah dokumen, menggunakan data cakupan pemeriksaan kehamilan minimal 4 kali (K4) dan Pertolongan Persalinan, terhadap ibu hamil dan bersalin dari keluarga miskin. Kinerjanya dikatakan baik apabila rata-rata kedua cakupannya mencapai $90 \%$ atau lebih. ${ }^{6}$

\section{Hasil}

Berdasarkan penelitian ini diketahui bahwa kinerja bidan di desa dalam program JPKMM masih randah $(56,7 \%)$. Berdasarkan faktor penyebabnya, dari segi pembinaan menunjukkan sebagaian besar $(76,0 \%)$ bidan di desa tidak pernah mendapatkan pembinaan oleh Dinas Kesehatan, umumnya bidan di desa berdomisili di luar desa tempat tugas $(71,2 \%)$, mayoritas bidan di desa hanya mempunyai tanggung jawab satu desa saja (76\%), mayoritas bidan di desa tidak mempunyai pesaing di de- 
Tabel 1. Distribusi Responden Menurut Karakteristik Demografi dan Kinerja di Kabuapeten Aceh Selatan Tahun 2007

\begin{tabular}{|c|c|c|c|}
\hline Variabel & Katagori & $\mathbf{N}$ & $\%$ \\
\hline \multirow[t]{2}{*}{ Kinerja Bidan } & Kurang & 59 & 56.7 \\
\hline & Baik & 45 & 43.3 \\
\hline \multirow[t]{2}{*}{ Pembinaan Dinkes } & Tidak & 79 & 76.0 \\
\hline & Ada & 25 & 24.0 \\
\hline \multirow[t]{2}{*}{ Persepsi Imbalan } & Kurang & 38 & 36.5 \\
\hline & Baik & 66 & 63.5 \\
\hline \multirow[t]{2}{*}{ Domisili } & Di luar desa tugas & 74 & 71.2 \\
\hline & Dalam desa tugas & 30 & 28.8 \\
\hline \multirow[t]{2}{*}{ Jumlah Desa } & $>1$ desa & 25 & 24.0 \\
\hline & 1 desa & 79 & 76.0 \\
\hline \multirow[t]{2}{*}{ Layanan kebidanan lain } & Tidak ada & 72 & 69.2 \\
\hline & Ada & 32 & 30.8 \\
\hline \multirow[t]{2}{*}{ Status Kepegawaian } & PTT & 31 & 29.8 \\
\hline & PNS & 73 & 70.2 \\
\hline \multirow[t]{2}{*}{ Tingkat Pendidikan } & D1 & 89 & 85.6 \\
\hline & D3 & 15 & 14.4 \\
\hline \multirow[t]{2}{*}{ Status Pernikahan } & Belum menikah & 12 & 11.5 \\
\hline & Sudah menikah & 92 & 88.5 \\
\hline \multirow[t]{2}{*}{ Pengetahuan JPKMM } & Kurang & 25 & 24.0 \\
\hline & Baik & 79 & 76.0 \\
\hline \multirow[t]{2}{*}{ Kemampuan kerja } & Kurang & 51 & 49.0 \\
\hline & Baik & 53 & 51.0 \\
\hline \multirow[t]{2}{*}{ Sikap kerja } & Kurang & 50 & 48.1 \\
\hline & Baik & 54 & 51.9 \\
\hline \multirow[t]{2}{*}{ Motivasi kerja } & Rendah & 48 & 46.2 \\
\hline & Tinggi & 56 & 53.8 \\
\hline
\end{tabular}

sanya $(69,2 \%)$. Sebagian besar bidan di desa mempunyai persepsi yang baik $(66,5 \%)$ terhadap imbalan yang diterimanya. Pada umumnya bidan di desa mempunyai status sebagai Pegawai Negeri Sipil (PNS) $(70,2 \%)$, mayoritas bidan di desa mempunyai pendidikan D1 $(85,6 \%)$, dari distribusi status pernikahan terlihat paling banyak bidan di desa sudah menikah $(88 \%)$. Pengetahuan bidan di desa tentang pelayanan kebidanan program JPKMM mayoritas baik $(76,0 \%)$. Kemampuan bidan di desa baik $(51,0 \%)$. Bidan di desa mempunyai sikap yang baik terhadap program kebidanan JPKMM (51,9\%), motivasi bidan di desa dalam melaksanakan pelayanan kebidanan program JPKMM sebagian besar $(53,8 \%)$ memiliki motivasi tinggi. Hasil analisis menunjukkan bahwa rata-rata umur bidan di desa adalah 31,32 tahun dengan standar deviasi 3,73 tahun. Umur termuda 22 tahun dan umur tertua 44 tahun (Lihat Tabel 1).

\section{Analisis Bivariat untuk Seleksi Kandidat Model}

Hasil analisis kasar (crude analysis) pada Tabel 2 diketahui dari 13 (tiga belas) variabel yang dianalisis didapatkan 4 (empat) variabel yang mempunyai hubungan bermakna secara statistik yaitu dengan nilai-p kurang dari 0,05 yaitu variabel motivasi, pengetahuan, pembinaan, dan pemberi layanan kebidanan lain (Lihat Tabel 2). Bidan di desa cenderung memiliki kinerja yang baik apabila mendapatkan pembinaan secara teratur dari
Tabel 2. Distribusi Responden Menurut Variabel yang Diamati

\begin{tabular}{|c|c|c|}
\hline Variabel & Katagori & $P$ value \\
\hline Status Pernikahan & $\begin{array}{l}\text { Belum menikah } \\
\text { Sudah menikah }\end{array}$ & 0.668 \\
\hline Status kepegawaian & $\begin{array}{l}\text { PTT } \\
\text { PNS }\end{array}$ & 0.638 \\
\hline Tingkat pendidikan & $\begin{array}{l}\text { D1 } \\
\text { D3 }\end{array}$ & 0.570 \\
\hline Pengetahuan & $\begin{array}{l}\text { Kurang } \\
\text { Baik }\end{array}$ & $0.008 *$ \\
\hline Kemampuan & $\begin{array}{l}\text { Kurang } \\
\text { Baik }\end{array}$ & 0.692 \\
\hline Sikap & $\begin{array}{l}\text { Kurang } \\
\text { Baik }\end{array}$ & 0.957 \\
\hline Motivasi & $\begin{array}{l}\text { Rendah } \\
\text { Tinggi }\end{array}$ & $0.013 *$ \\
\hline Umur & $\begin{array}{l}\text { Mean } \\
\text { SD }\end{array}$ & 0.485 \\
\hline Faktor Organisasi & & \\
\hline Pembinaan & $\begin{array}{l}\text { Tidak } \\
\text { Ada }\end{array}$ & $0.030 *$ \\
\hline Imbalan & $\begin{array}{l}\text { Kurang } \\
\text { Baik }\end{array}$ & 0.699 \\
\hline Domisili Bidan di desa & $\begin{array}{l}\text { Luar desa tempat tugas } \\
\text { Dalam desa tempat tugas }\end{array}$ & 1.000 \\
\hline Jumlah desa & $\begin{array}{l}>1 \text { desa } \\
1 \text { desa }\end{array}$ & 0.214 \\
\hline Layanaan kebidanan lain & $\begin{array}{l}\text { Ada } \\
\text { Tidak ada }\end{array}$ & $0.001 *$ \\
\hline
\end{tabular}

* Bermakna secara statistik pada alpha 0.05

dinas kesehatan ataupun puskesmas dan tidak ada pesaing atau tenaga kesehatan lain yang memberikan pelayanan kebidanan di desa tersebut. Kinerja bidan di desa juga akan lebih baik apabila mereka memiliki pengetahuan yang baik tentang program Jaminan Pelayanan Kesehatan Masyarakat Miskin (JPKMM) dan motivasi kerja yang tinggi.

\section{Analisis Multivariat}

Analisis multivariat dilakukan untuk menentukan variabel yang berhubungan dengan kinerja bidang di desa, setelah dikontrol oleh variabel lainnya. Variabel yang masuk ke dalam model adalah yang bermakna secara statistik (nilai-p kurang dari 0,05). Berdasarkan model akhir regresi logistik terlihat bahwa variebel yang berhubungan dengan kinerja bidan di desa dalam pelayanan kebidanan program JPKMM di Kabupaten Aceh Selatan tahun 2007 adalah variabel-variabel pemberi pelayanan kebidanan lain/pesaing, pembinaan, motivasi dan pengetahuan. Bidan di desa yang tidak mempunyai pemberi layanan kebidanan lain/pesaing di wilayah tugasnya mempunyai peluang 14 kali lebih besar untuk berkinerja baik dibandingkan bidan di desa yang mempunyai pemberi layanan kebidanan lain di wilayah tugasnya. Bidan di desa yang mendapat pembinaan dengan baik dari dinas kesehatan mempunyai peluang 3,9 kali berkinerja baik dibandingkan bidan di desa yang tidak mendapat pembinaan. 
Tabel 3. Model Multivariat Regresi Logistik Kinerja Bidan di Desa di Kabupaten Aceh Selatan Tahun 2007

\begin{tabular}{llccc}
\hline Variabel & Kategori & Nilai P & Odds Ratio & 95\% CI OR \\
\hline Pembinaan & $\begin{array}{l}\text { Tidak Ada } \\
\text { Ada }\end{array}$ & 0.035 & 3.92 & $1.10-13.91$ \\
Pesaing & $\begin{array}{l}\text { Tidak Ada } \\
\text { Ada }\end{array}$ & 0.0001 & 14.46 & $3.82-54.68$ \\
Pengetahuan & $\begin{array}{l}\text { Kurang } \\
\text { Baik } \\
\text { Mendah }\end{array}$ & 0.004 & 0.14 & $0.04-0.53$ \\
& $\begin{array}{l}\text { Tinggi } \\
\text { Motivasi }\end{array}$ & 0.041 & 2.78 & $1.04-7.39$ \\
\hline
\end{tabular}

Bidan di desa yang mempunyai motivasi tinggi mempunyai peluang 2,7 kali berkinerja baik dibandingkan bidan di desa yang mempunyai motivasi rendah. Bidan di desa yang mempunyai pengetahuan baik berpeluang 0,14 untuk mempunyai kinerja baik dibandingkan bidan di desa yang mempunyai pengetahuan rendah (Lihat Tabel 3).

\section{Pembahasan}

Hasil penelitian ini memperlihatkan bahwa kinerja bidan di desa Kabupaten Aceh Selatan tahun 2007 masih kurang $(56,7 \%)$. Kinerja bidan di desa di ukur dari gabungan pencapaian $\mathrm{K} 4$ dengan pertolongan persalinan oleh bidan tersebut. Bila dibandingkan dengan penelitian lain tentang kinerja bidan di desa, penelitian ini menunjukan hasil yang hampir sama. Hasil penelitian Pipo tahun 1999 tentang kinerja bidan di desa Kabupaten Pariaman menyatakan kinerja bidan masih kurang $(56,5 \%) .{ }^{8}$ Kinerja bidan di desa yang masih kurang ini dapat disebabkan oleh pesaing, tugas rangkap bidan, tradisi melahirkan di kampung orang tua, dan pembinaan bidan desa yang kurang.

Pesaing adalah pelayanan kebidanan lain yang berada di wilayah desa tempat bidan di desa bertugas. Analisis bivariat memperlihatkan bahwa bidan di desa yang tidak ada pesaing, mampu berkinerja baik (56,9\%), sedangkan bila ada pesaing (ada pemberi layanan kebidanan lain di wilayah tempat tugas) kinerja baiknya hanya sebanyak $(12,5 \%)$. Penyebab lain rendahnya kinerja bidan di desa ini adalah tugas rangkap bidan di desa. Selain bertugas di desa melaksanakan pelayanan kebidanan, mereka juga bekerja di puskesmas, sehingga bidan di desa tidak bisa melaksanakan pelayanan kebidanan secara maksimal di desanya. Mereka bekerja rangkap karena puskesmas kekurangan tenaga.

Kinerja bidan di desa yang rendah itu juga dimungkinkan oleh kebiasaan atau tradisi masyarakat di daerah Aceh Selatan. Ibu hamil yang menjelang melahirkan akan pulang ke rumah orang tuanya yang terkadang berada di daerah lain atau luar kabupaten. Hal ini menyebabkan bi- dan di desa yang ada di desa tempat tinggal ibu hamil tersebut tidak dapat melaksanakan pertolongan persalinan. Di tempat orang tuanya, biasanya orang tuanya akan menganjurkan untuk bersalin dengan dukun beranak. Hasil analisis multivariat memperlihatkan bahwa pembinaan merupakan faktor yang signifikan berhubungan dengan kinerja bidan di desa. Hasil penelitian ini sesuai dengan penelitian lain yang menunjukan hubungan bermakna antara pembinaan dengan kinerja yaitu penelitian yang dilakukan oleh Pipo, ${ }^{8}$ di Kabupaten Pariaman. Tetapi, ada penelitian lain yang tidak sesuai yang menyatakan tidak ada hubungan yang bermakna antara pembinaan dengan kinerja bidan di desa. ${ }^{9}$ Pembinaan yang dilakukan oleh dinas kesehatan dan puskesmas kepada bidan di desa baik dalam hal kualitas maupun kuantitas ternyata masih kurang. Tiga dari empat responden menyatakan tidak mendapatkan pembinaan dari atasannya. Dengan demikian, disarankan kepada dinas kesehatan ataupun pihak puskesmas, agar meningkatkan upaya memberikan pembinaan, bimbingan, dan arahan kepada bidan di desa di wilayah kerjanya secara terencana dan terjadwal.

Hasil analisis multivariat diketahui bahwa pengetahuan merupakan faktor yang berhubungan dengan kinerja bidan di desa. Pengetahuan bidan di desa tentang program pelayanan kebidanan JPKMM, umumnya bidan di desa mengetahui: tentang kriteria sasaran yang seharusnya mendapat pelayanan kebidanan program JPKMM, kegiatan pencatatan kegiatan pelayanan kebidanan menggunakan kohort, patograf dan buku bantu kegiatan, cara mengambil uang di rekening puskesmas, pengiriman laporan dan kegunaan laporan hasil pencatatan dan pelaporan. Namun, masih terdapat dimensi pengetahuan yang kurang mereka pahami seperti target yang harus dicapai dalam pelayanan kebidanan program JPKMM dan kegunaan biaya pelayanan kebidanan. Hendaknya dinas kesehatan dan puskesmas memberikan bimbingan yang lebih khusus pada dimensi target yang harus dicapai dalam pelayanan kebidanan program JPKMM dan kegunaan biaya pelayanan kebidanan. 
Motivasi bidan di desa dalam melaksanakan pelayanan kebidanan program JPKMM merupakan faktor yang berhubungan dengan kinerja. Hasil penelitian ini sejalan dengan hasil penelitian yang dilakukan Umar, ${ }^{10}$ menyatakan terdapat hubungan bermakna antara motivasi dengan kinerja bidan di desa di Kabupaten Batang Hari, namun berbeda dengan penelitian yang dilakukan oleh Rumisis, ${ }^{11}$ yang menyatakan tidak terdapat hubungan bermakna antara motivasi dengan kinerja bidan di desa di Kabupaten Indragiri Hilir. Motivasi bidan di desa dalam melaksanakan pelayanan kebidanan di Kabupaten Aceh Selatan sudah cukup baik, hal ini diketahui dari tingginya nilai rata-rata pernyataan motivasi, dan nilai rata-rata tertinggi adalah pernyataan motivasi-5 yaitu pelayanan kebidanan dilakukan dengan baik karena rasa ingin menolong sesama.

Hasil analisis multivariat juga memperlihatkan bahwa adanya pesaing atau pemberi layanan kebidanan lain merupakan faktor yang paling dominan berhubungan dengan kinerja bidan di desa. Memberikan pelayanan kebidanan program JPKMM di wilayah tugas bidan di desa merupakan tugas dan tanggung jawab dari bidan di desa itu sendiri, namun apabila ada pesaing, maka pasien bisa mendapatkan pelayanan kebidanan program JPKMM dari bidan lain (pesaing) di desa tersebut. Apabila ada pesaing dalam memberikan pelayanan kebidanan program JPKMM, otomatis bidan di desa tidak bisa memonopoli pelayanan kebidanan, yang akhirnya berdampak pada menurunnya kinerja dari bidan di desa tersebut. Hasil studi ini memperlihatkan bahwa status kepegawaian tidak berhubungan dengan kinerja bidan di desa, artinya Bidan PNS dan PTT memiliki kinerja yang sama. Penelitian ini berbeda dengan penelitian yang dilakukan oleh Suganda, ${ }^{9}$ yang melaporkan adanya perbedaan bermakna antara kinerja Bidan PNS dengan Bidan PTT, dimana Bidan PNS mempunyai kinerja yang lebih baik dibandingkan dengan Bidan PTT. Bidan yang sudah menikah mempunyai kinerja yang lebih baik dibandingkan dengan bidan yang belum menikah, namun tidak bermakna secara statistik. Hal ini sejalan dengan penelitian yang dilaksanakan Pipo, ${ }^{8}$ di Kabupaten Pariaman.

Walaupun bidan yang berpendidikan D3 lebih baik kinerjanya dibandingkan D1, namun secara statistik perbedaan tersebut tidak bermakna. Hasil ini sejalan dengan penelitian Maimunah, ${ }^{12}$ di Kuta Baro Kabupaten Aceh Besar yang menyatakan pendidikan bidan di desa tidak berhubungan dengan kinerjanya. Hasil penelitian juga diketahui tidak terdapat hubungan bermakna antara kinerja bidan di desa yang berdomisili di dalam desa dengan bidan di desa yang berdomisili di luar desa tempat tugas. Penelitian ini sejalan dengan penelitian yang dilakukan oleh Suganda, ${ }^{9}$ bahwa tidak ada perbedaan yang bermakna antara domisili bidan dengan kinerja bi- dan di desa.

Sikap bidan juga tidak berhubungan dengan kinerjanya. Hal yang sama juga dilaporkan oleh Fajriana, ${ }^{13}$ di Kabupaten Aceh Tengah. Umur bidan juga tidak berhubungan dengan kinerjanya. Hal ini juga sejalan dengan penelitian yang dilakukan oleh Pipo, ${ }^{8}$ di Pariaman. Hasil penelitian ini menunjukkan bahwa tidak ada hubungan yang bermakna antara imbalan dengan kinerja bidan di desa. Hasil ini berbeda dengan hasil penelitian yang dilakukan oleh Rosidin. ${ }^{14}$ Pesaing atau pemberi layanan kebidanan lain merupakan variabel yang paling dominaan berhubungan dengan kinerja bidan di desa, dimana bidan di desa yang tidak mempunyai pesaing dalam wilayah tugasnya berpeluang 14 kali lebih besar untuk berkinerja baik dibandingkan bidan di desa yang memiliki pesaing. Pesaing adalah pemberi layanan kebidanan lain dalam wilayah tugasnya, berupa bidan di desa lain, bidan swasta, atau bidan puskesmas yang melaksanakan pelayanan kebidanan di wilayah kerja si bidan di desa tersebut.

Terdapat dua sisi yang ditimbulkan dalam persaingan, yaitu kunci kesuksesan karena mendorong bidan di desa untuk lebih dinamis dalam bersaing dalam memberikan layanan terbaik dalam pelayanan kebidanan program JPKMM, sehingga persaingan dianggap peluang yang memotivasi dan pada akhirnya dapat meningkatkan kinerja bidan di desa tersebut. Sedangkan, sisi lainnya adalah kegagalan karena akan memperlemah bidan di desa yang statis, takut akan persaingan dan tidak mampu memberikan pelayanan yang terbaik, sehingga pesaing menjadi ancaman yang akan menurunkan kinerja bidan di desa tersebut. ${ }^{15}$ Untuk sukses dalam persaingan seorang bidan di desa harus mampu memberikan pelayanan terbaik bagi pasien, proaktif mendatangi pasien ke rumah, memelihara hubungan sosial yang baik dengan pasien dan terus-menerus melakukan perbaikan-perbaikan dalam memberikan pelayanan kepada pasien. Seorang bidan di desa harus mempunyai ciri khas atau produk unggulan yang dapat membedakan bidan di desa tersebut dengan pesaing, misalnya bidan di desa tersebut dalam memberikan pelayanan selalu menerapkan prinsip $3 \mathrm{~S}$ (salam, senyum dan sopan).

\section{Kesimpulan}

Kinerja bidan di desa dalam pelayanan kebidanan di Kabupaten Aceh Selatan masih kurang (56,7\%). Faktorfaktor yang berhubungan dengan rendahnya kinerja bidan di desa Kabupaten Aceh Selatan adalah masih kurangnya pembinaan oleh dinas kesehatan dan adanya bidan pesaing di desa tempat bertugas, pengetahuan, dan motivasi yang masih rendah. Kinerja bidan di desa tidak ditentukan oleh domisili bidan (tinggal di desa atau tidak) dan jumlah desa yang menjadi tanggung jawabnya, umur, pernikahan, status pegawai (PNS/PTT), pendidikan (D1/D3), ataupun sikap dan kemampuan. 
Saran

Disarankan kepada Dinas Kesehatan Kabupaten Aceh Selatan agar lebih meningkatkan pembinaan, bimbingan, dan arahan kepada semua bidan di desa secara terencana dan lebih meningkatkan pemberian penghargaan kepada bidan yang berprestasi untuk memacu motivasi kerja mereka. Kepada bidan di desa disarankan untuk terus-menerus melakukan perbaikan dalam pelayanan kepada pasien dan dalam memberikan pelayanan kebidanan selalu menerapkan prinsip $3 \mathrm{~S}$ (salam, senyum dan sopan) serta proaktif mendatangi pasien ke rumahnya untuk memberikan pelayanan kebidanan ataupun memelihara hubungan sosial yang baik.

\section{Daftar Pustaka}

1. Departemen Kesehatan RI. Profil kesehatan RI. Jakarta: Departemen Kesehatan RI; 2002.

2. Departemen Kesehatan RI. Perencanaan strategis nasional making pregnancy safer (MPS) di Indonesia 2001 - 2010. Jakarta: Departemen Kesehatan RI; 2001.

3. Departemen Kesehatan RI. Keputusan menkes RI no: 1212/MENKES/SK/IX/2002 tentang petunjuk teknis pelaksanaan pengangkatan bidan sebagai pegawai tidak tetap. Jakarta: Departemen Kesehatan RI; 2002.

4. Dinas Kesehatan Kabupaten Aceh Selatan. Profil dinas kesehatan kabupaten Aceh Selatan. Tapaktuan: Dinas Kesehatan Kabupaten Aceh Selatan; 2005.

5. Dinas Kesehatan Kabupaten Aceh Selatan. Laporan pelaksanaan kegiatan dan keuangan program JPKMM. Tapaktuan: Dinas Kesehatan
Kabupaten Aceh Selatan; 2006.

6. Departemen Kesehatan RI. Pedoman pelaksanaan jaminan pemeliharaan kesehatan masyarakat miskin. Jakarta: Departemen Kesehatan RI; 2006.

7. Gibson. Organisasi, perilaku, struktur dan proses. Edisi Kelima. Jakarta: Erlangga; 1997.

8. Pippo. Analsis faktor internal dan faktor eksternal yang berhubungan dengan kinerja bidan di desa sebagai PTT [tesis]. Depok: Universitas Indonesia; 2000.

9. Suganda. Faktor-faktor yang berhubungan dengan Kineja bidan di desa di Kabupaten Tasikmalaya tahun 1997 [tesis]. Depok: Universitas Indonesia; 1997.

10. Umar. Faktor-faktor yang berhubungan dengan kinerja bidan di desa dalam pelayanan antenatal (ANC) berdasarkan standar pelayanan kebidanan di Kabupaten Batang Hari Propinsi Jambi tahun 2007 [tesis]. Depok: Universitas Indonesia; 2007.

11. Rumisis. Faktor-faktor yang berhubungan dengan Kinerja bidan di desa di Kabupaten Indra Giri Hilir Riau tahun 2002 [tesis]. Depok: Universitas Indonesia; 2002.

12. Maimunah. Faktor-faktor yang berhubungan dengan kinerja pelayanan kesehatan ibu hamil (ANC) oleh bidan di desa di Kabupaten Aceh Besar tahun 1999 [tesis]. Depok: Universitas Indonesia; 1999.

13. Fajriana. Faktor-faktor yang berhubungan dengan kinerja bidan dalam pertolongan persalinan di Kabupaten Aceh Tengah tahun 2000 [tesis]. Depok: Universitas Indonesia; 2000.

14. Rosidin. Faktor-faktor yang berhubungan dengan kinerja bidan di desa di Kabupaten Karawang [tesis]. Depok: Universitas Indonesia; 2001.

15. Muhardi. Strategi operasi untuk keunggulan bersaing. Yogyakarta: Graha Ilmu; 2008. 